\title{
THE EFFECT OF SCRAMBLE GAME TOWARDS THE ABILITY OF COMPOSING SENTENCES FOR STUDENTS WITH INTELLECTUAL DISABILITY
}

\author{
Noverita Surya Dewia , Agung Kurniawan ${ }^{\mathrm{b}}$ \\ ${ }^{a}$ Department of Special Education, State University of Malang, Indonesia \\ ${ }^{b}$ Faculty of Sport Science, State University of Malang, Indonesia \\ Email: kurniawan1974agung@gmail.com
}

\begin{abstract}
Children with intellectual disability have limitations in language acquisition mainly in processing vocabulary that is less functioning as it is expected, that is why they fell difficulty in preparing sentence. The purpose of this study was to describe the effects of the scramble games toward capability of sentence composition for students with intellectual disability. The method used is a quasi-experimental design with time series design. This study showed there was a difference capability of sentence composition for students with intelllectual disability before and after treatment with scramble game. It is shown from the results of $t$ arithmetic $<t$ table at significant level of 0.05 is $0<1$. The conclusion of this study was the scramble game affect toward capability of sentence composition for students with intellectual disability.
\end{abstract}

Keywords: scramble game, sentence composition, intellectual disability

According Branata in Efendi (2006:88) someone who is categorized into intellectual disabilities or mental retardation, if he has a level of intelligence is so low (below normal) to pursue development tasks requiring specific assistance or services, including in the educational process. Retarded children have limitations in language acquisition. They have difficulty in articulation, the processing center (vocabulary) works less properly. For that reason, they need concrete words that are often heard. Besides, the differences and similarities must be shown repeatedly. Simple exercises to teach concepts such as big and small, hard and weak, first, second, and last, it is necessary to use concrete approach (Soemantri, 2007:106).

Suparno in Dames (2012:4) states that the scramble method is one of the language games. Basically, the language game is an activity to acquire specific skills in a way of encouraging. Budinuryanto in the Guntur (2013:21) states that the technique scramble is a game development or sorting a language structure that previously has been confused arrangement deliberately. Fitriyah in Saputra and Fatmasari (2015:173) states that in this scramble game, the students' activeness and creativity are important because these two components make the students not growing. The game is also able to optimize the students to think more creatively to define and construct a new thing or structure so that it can increase knowledge and understanding because students are active in the game. The accuracy and speed of thinking in answering the question becomes one of the key games in scramble learning methods.

At the time of observation in retarded students of class VIII in SLB Lawang, researchers discovered the problem as follows: students find difficulties to make simple sentences based on the pictures in textbooks. To overcome this difficulty, the researchers took the initiative to facilitate the students to do the work by writing down all of the objects in term of the pictures in textbooks. For example, in the picture there are flowers, cat, house, yard, and others. Then the researchers asked the students about one of the objects. What was the cat doing? And the student answered the cat was eating. Then the researchers asked where? Then students answer on the terrace home. From that question then the students can make sentences based on the pictures in textbooks. Therefore, the researcher conducted a study with a titled "The Effect Of Scramble Game Towards The Ability Of Composing Sentences For Students With Intellectual Disability In The Grade VIII in SLB Pembina Nasional, Lawang".

The purpose of this study was to describe the Effect of Scramble Game towards the Ability of Composing Sentences for Students with Intellectual disability of the Grade VIII in SLB Pembina Nasional, Lawang". This research is expected to be a reference for teachers and schools to solve the problems in learning activities in the classroom.

\section{METHOD}

Sugiyono (2014:72) mentions that experimental research is defined as research methods used to find a specific treatment effect towards the other in 
uncontrolled conditions. So, this study was aimed at investigating the effect of the game scramble usage towards the ability of composing sentences.

The quasi experimental method was used in this research with time series design. It was given eight tests before and after the intervention. The 4 test before the intervention $(\mathrm{O} 1, \mathrm{O} 2, \mathrm{O} 3, \mathrm{O} 4)$ was called a pre-test and the 4 test before the intervention (O5, O6, O7, O8) called a post-test. The subjects used in this study were 5 students with mild mental retardation of class VIII in SLB Pembina Nasional C, Lawang.

The instruments were 10 points the written test. The test was given before being given intervention (pre-test) and after being given intervention (posttest). The data analysis was quantitative data with non parametric technique. For determining differences of the ability to compose sentence for students with intellectual disability before and after the Scramble game usage with Wilcoxon rank test.

\section{FINDINGS AND DISCUSSION}

\section{Findings}

From this research, it was obtained two kinds of data such as beginning and final capabilities for students with intellectual disability to compose sentences. The preliminary data is a data that shows the ability of the students before being given interventions. Students' initial capability that was obtained from the pre test was done before the given intervention. The pre test were 10 questions. The pre test was done four times in order to get stability. Then, the final data was the student's ability to construct a sentence after being given the intervention. The data that was obtained from the ability of the student's final post-test results are being given after intervention. The post test were 4 times with the aim to determine the effectiveness of interventions.

Table 1. Pre Test and Post Test Value

\begin{tabular}{|c|c|c|c|c|c|c|c|c|c|c|c|}
\hline \multirow[t]{2}{*}{ No } & \multirow{2}{*}{$\begin{array}{l}\mathrm{Na} \\
\mathrm{me}\end{array}$} & \multicolumn{4}{|c|}{ Pre Test Value } & $\mathrm{S}$ & \multicolumn{4}{|c|}{ Post Test Value } & \multirow[t]{2}{*}{ Sum } \\
\hline & & I & II & III & IV & $\begin{array}{l}\mathrm{U} \\
\mathrm{M}\end{array}$ & I & II & III & IV & \\
\hline 1 & ZM & 7 & 8 & 7 & 8 & 30 & 8 & 8 & 8 & 9 & 33 \\
\hline 2 & TA & 3 & 4 & 3 & 4 & 14 & 7 & 7 & 8 & 8 & 30 \\
\hline 3 & FA & 5 & 5 & 5 & 5 & 20 & 7 & 7 & 8 & 9 & 31 \\
\hline 4 & RJ & 3 & 4 & 3 & 4 & 14 & 7 & 7 & 8 & 8 & 30 \\
\hline 5 & FR & 9 & 9 & 9 & 9 & 36 & 10 & 10 & 10 & 10 & 40 \\
\hline & & & & & & 5,7 & & & $\mathrm{rage}$ & & 8,2 \\
\hline
\end{tabular}

From the above table, there was only one of 5 students who get very good value. The average value of the initial capability class was 5.7. The result of posttest from 5 students was a very good. The average value of the final capability was 8.2 .
Graph 1. The value result of Pre Test and Post Test

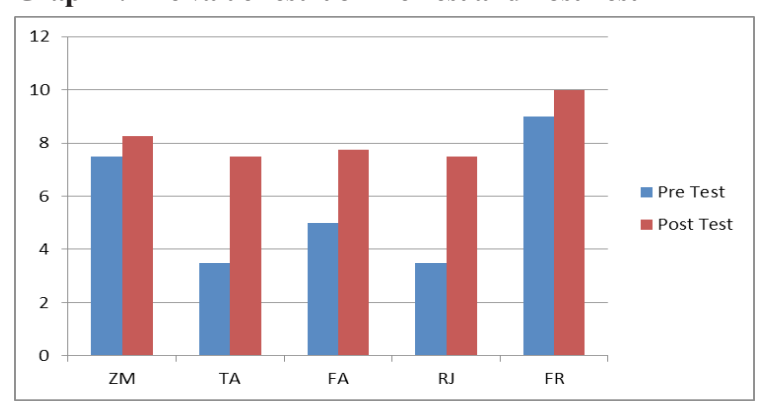

From the above graph, it can be seen that there is an increase learning outcomes of the students' ability to compose sentences after being treated by using a scramble game. The data obtained from the pre-test and post test was then analyzed by using the Wilcoxon signed rank test as follows:

Table 2. Wilcoxon Test

\begin{tabular}{lllllll}
\hline No & $\begin{array}{l}\text { P r e } \\
\text { test }\end{array}$ & $\begin{array}{l}\text { Post diff } \\
\text { test }\end{array}$ & $\begin{array}{l}\text { Absolut } \\
\text { diff }\end{array}$ & $\begin{array}{l}\text { Rank } \\
\text { absolut }\end{array}$ & $\begin{array}{l}\text { dif } \\
\text { Signed } \\
\text { ranks }\end{array}$ \\
\hline 1 & 7.5 & 8.25 & 0.75 & 0.75 & 2 & 2 \\
2 & 3.5 & 7.5 & 4 & 4 & 4.5 & 4.5 \\
3 & 5 & 7.75 & 2.75 & 2.75 & 3 & 3 \\
4 & 3.5 & 7.5 & 4 & 4 & 4.5 & 4.5 \\
5 & 9 & 10 & 1 & 1 & 1 & 1 \\
$\mathrm{~T}$ (positive) $=15$ & & & & \\
$\mathrm{~T}$ (negative) $=0$ & & & & \\
\hline
\end{tabular}

From the table 4.2, $\mathrm{t}$ table with for 5 samples with significance level of 0.05 is 1 and t counting is 0 of the smallest rank. T counting $<\mathrm{t}$ table so that $\mathrm{Hi}$ is received. Based on the above results, it can be concluded that there are differences in students' ability to construct sentences between before and after using the scramble game. Thus, the scramble game was affected the ability to compose sentences for students with intellectual disability in the grade VIII.

\section{Discussion}

Based on the results of the pre-test before being given treatment there are some students who have difficulty to make sentences. This is evident from the results of the students are judged less than 6 . The students with intellectual disability have a low memory. Related to memory, Somantri (2007:112) states that the retarded children are different from normal children on a short term memory. A retarded child does not seem different from normal children. But evidence suggests children with mental retardation are different from normal children in terms of immediate recall.

In this study, children with intellectual disability do problem in constructing a sentence without using the learning methods for a given test prior to the 
treatment using the scramble game. Learning to make sentences for children with intellectual disability is difficult without the use of learning methods. Somantri (2007:105) mentions the learning capacity of children with intellectual disability especially that such abstract learning sucha as arithmetic, writing and reading is also limited. Therefore, the ability to construct phrases for retarded students of class VIII in SLB Pembina National Lawang before being given learning of game scramble getting less value.

The ability to construct phrases for students with intellectual disability in grade VIII of SLB Pembina National Lawang after being given treatment namely using scramble game get better results than before. The students are no longer experiencing difficulty in preparing sentence. This is in line with Harjasujana in Suratno (2014:29) through the scramble technique, The students are not only invited to train the mind to predict the way the original authors but also encouraged to be creative with a new arrangement and it is better than the original arrangements. It is concluded that the learning techniques scramble is learning techniques that provide insight into the development and improvement of an organization preparing students in writing so that it becomes an intact article. In addition to train students to be more creative to find phrase better than the original arrangement.

The usage of scramble games in learning to compose sentences make the students more aware of the learning rather than merely explained in the abstract without learning methods. With the Scramble game, students can understand the material being taught teachers to make sentences. Use of games in learning in line with the Trisanti's opinion in Saputra and Ratnasari (2015:173) states that the game media is media that can reduce the saturation of the students, giving pleasure and knowledge. So the game is a fun activity that can make students happy in the process of learning so that students are not saturated in receiving information from the teacher.

In the teaching and learning process, learning activities can run without tools, but without the learning method, the learning will hinder the teaching learning process. Teachers are expected to take advantage of learning methods in teaching and learning. The key to successfully learning is the teacher. When learning to construct phrases scramble teachers can utilize the game as a learning method.

The game scramble in learning to make sentences influence on student achievement for mild mental retardation in class VIII of SLB Pembina. Based on the results of hypothesis testing showed that there was different usage of Scramble game on the ability to make sentences. From table 4.5 discovered that the average pre-test was 5.7 and post test was 8.2 by comparing the average value of the ability to make sentences before and after being given scramble game. In table 4.5 it can be concluded, the use of the game Scramble have influence on the ability to construct phrases for retarded students of class VIII. The average of post test was better than the pre test because after being given pre-test, the teacher can analyze the weaknesses of the students. Referring to the analysis of the results of the pre-test teachers can provide treatment using Scramble game to overcome weaknesses in preparing sentence.

The results of this study was using the formula of Wilcoxon test, to determine differences in the use of the game Scramble on the ability to construct phrases retarded students of class VIII in SLB Pembina National. The result showed that the value of T obtained in the count is 0 of rank smallest whereas for $\mathrm{T}$ table at 0,05 significant level is 1 for $\mathrm{T}$ count is smaller than $\mathrm{T}$ table then the null hypothesis is rejected and the working hypothesis is accepted. This means that there was an increased ability to make sentences for retarded students of class VIII using scramble game in SLB Pembina National.

Based on research results using Wilcoxon test stated that Ho refused and $\mathrm{Hi}$ accepted, it indicated that there was a significant difference in the ability to construct phrases for retarded students of class VIII in SLB Pembina National using scramble game. The statement can be proved by the increase in the results of tests that have been given, from the recapitulation of pre test and post test increased during the post-test after being given treatment. Therefore it is proven that the use of a game scramble in preparing sentence is the appropriate treatment to optimize the ability to construct phrases for retarded students of class VIII in SLB Pembina National.

The results of this study can complement and support the research conducted by Fatmasari (2015) with the title "The Effect of Scramble Method Implementation towards Capabilities of Composing Sentence for students with hearing Impairment in grade V of SDLB Class-B Dharma Wanita Sidoarjo". Research results showed that there were differences in learning outcomes of constructing a sentence using the scramble. Basically the use of scramble method in learning to make sentences in previous studies almost the same except that the subjects used in the study are different, if in the previous research use students with hearing Impairment as research subjects, this study used the retarded students as research subjects.

Learning construct a sentence using the Scramble game can improve the quality of learning for the learning process does not feel bored and boring. From the use of games scramble in learning makes students more improving learning achievement. The subject matter is usually only the abstract will be more easily understood by students when utilizing the game in learning. 


\section{CONCLUSIONS AND SUGGESTION}

Based on the research that has been done can be concluded that the ability to make sentences for eighth grade students with intellectual disability in SLB Pembina National before being given scramble game get average value of 5.7, which means less. Only one student who received score pre-test is very good. The ability to construct phrases for eighth grade students with intellectual disability in SLB Pembina after being given scramble game has increased. It can be seen from the average value of post test of 8.2, which means good.

There is a scramble game influence on the ability to construct phrases for retarded students of class VIII in SLB Pembina National Level. Based on the hypothesis testing results indicate that there are

\section{REFERENCES}

Dames, Poppy. 2012. Pengaruh Penggunaan Metode Scramble Terhadap Hasil Belajar Ilmu Pengetahuan Sosial Siswa Kelas IV Semester II Sekolah Dasar Negeri Sidorejo Lor 02 Salatiga Tahun Pelajaran 2011/2012. Skripsi tidak diterbitkan. Salatiga. Fakultas Keguruan Dan Ilmu Pendidikan.Universitas Kristen Satya Wacana

Efendi, Mohammad. 2006. Pengantar Psikopedagogik Anak Berkelainan. Jakarta: PT Bumi Aksara

Fatmasari, Eryana. 2015. Pengaruh Penerapan Metode Scramble Terhadap Kemampuan Menyusun Kalimat Anak Tunarungu Kelas V SDLB-B Dharma Wanita Sidoarjo. Jurnal Ilmu Pendidikan, (Online), 2-8, (http:// ejournal.unesa.ac.id/ article/16316/15/article.pdf), diakses 21 April 2016

Guntur, Andrealdus. 2013. Peningkatan Kemampuan Menyusun Kalimat Yang Diacak Menjadi Sebuah Paragraf Yang Baik Dan Benar Melalui Metode Scramble Pada Siswa Kelas V SDN 10 Kesiman Denpasar Tahun Pelajaran 2012/2013. Skripsi tidak diterbitkan. Fakultas Keguruan Dan Ilmu Pendidikan. Universitas Mahasaraswati Denpasar significant differences between the ability to make sentences before and after being guven scramble game that is value of $\mathrm{T}$ count $<\mathrm{T}$ table then $\mathrm{Hi}$ is accepted $\mathrm{Ho}$ is rejected.

Suggestions can be submitted is for the researchers can complete the deficiencies in the study of which may modify the procedures for this game according to the material to be delivered. For Teachers are encouraged to apply learning to use the games in particular scramble in language learning with materials to construct phrases to improve learning achievement so that students are interested to participate in learning. Then, for the school are expected to make use of the training program the game scramble for teachers with the aim to provide supplies to teachers.

Saputra, Henry \& Ratnasari, Dwi. 2015. Implementasi Permainan Scramble Pada Pembelajaran IPA Dengan Model Kooperatif Tipe ProbingPrompting Di Kelas $V$ SD Negeri. Jurnal Ilmu Pendidikan, (Online), 169-178, (http:// prosiding.upgrismg.ac.id/index.php/pgsd2015/ pgsd2015/.../506), diakses 21 April 2016

Somantri, Sutjihati. 2007. Psikologi Anak Luar Biasa. Bandung: PT Refika Aditama

Sugiyono. 2014. Metode Penelitian Kuantitatif, Kualitatif Dan $R \&$ D. Jakarta: Alfabeta

Suratno. Arif. 2014. Peningkatan Kemampuan Membaca Pemahaman Menggunakan Teknik Scramble Wacana Siswa Kelas IVA SDN Tukangan Yogyakarta. Skripsi tidak diterbitkan. Fakultas Ilmu Pendidikan. Universitas Negeri Yogyakarta 